\title{
Steady-State Cell Apoptosis and Immune Tolerance - Induction of Tolerance Using Apoptotic Cells in Type 1 Diabetes and Other Immune-Mediated Disorders
}

\author{
Chang-Qing Xia ${ }^{1}$, Kim Campbell2, \\ Benjamin Keselowsky ${ }^{3}$ and Michael Clare-Salzler ${ }^{1}$ \\ ${ }^{1}$ Department of Pathology, Immunology and Laboratory Medicine, University of Florida \\ ${ }^{2}$ Therakos \\ ${ }^{3}$ Department Bioengineering, University of Florida \\ USA
}

\section{Introduction}

Type 1 diabetes (T1D) is also named insulin-dependent diabetes mellitus. Because T1D is more frequently seen in children, it is also called juvenile diabetes. Currently the standard treatment for T1D is the daily use of exogenous insulin. Because of the poor compliance with insulin use, T1D patients often suffer from hyperglycemia or hypoglycemia $(1 ; 2)$. In addition, T1D patients are at high risk for experiencing ketoacidosis due to a variety of different reasons (3-5). Many T1D patients will inevitably develop serious, chronic complications in organs such as heart and kidney (6-9). Therefore, T1D is a devastating disease for young individuals. Thus far, there has been no cure for T1D, and the search for its cure is a long-term goal in T1D research.

Regarding the pathogenesis of T1D, it is clear that T1D is an autoimmune disease that is mediated by pathogenic $T$ cell responses to pancreatic islet $\beta$ cells (10-12). The fundamental problem in T1D is the breakdown of immune tolerance to self antigens. More specifically, $\beta$ cell antigen-specific T cells, which are usually well controlled in healthy individuals through various self tolerance mechanisms, attack insulin-producing $\beta$ cells. Thus, to cure T1D, restoration of immune tolerance against $\beta$ cell antigens is necessary. Numerous investigators have expended tremendous energy and efforts in finding ways to prevent or cure T1D; however, much work still remains.

During fetal development, the majority of self-reactive $\mathrm{T}$ cell clones are deleted in the thymus. This process is referred to as central tolerance. Some self-reactive $T$ cell clones do escape $\mathrm{T}$ cell deletion mechanisms and are exported to the periphery, leading to a potential risk for development of autoimmune diseases. In healthy individuals, self-reactive $\mathrm{T}$ cell clones are not pathogenic, because of well-functioning peripheral regulatory mechanisms $(13 ; 14)$. One of the major mechanisms by which self tolerance is maintained is through the steady-state processing of apoptotic cells during normal tissue turnover (14). Evidence has 
shown that the impaired processing of apoptotic cells is associated with the pathogenesis of systemic lupus erythematosus $(15 ; 16)$. In this chapter, we will focus on discussing the relationship between steady-state cell apoptosis and self-tolerance maintenance. In addition, we will discuss $\beta$ cell apoptosis and T1D pathogenesis as well as the application of intravenous apoptotic cell delivery in restoring immune tolerance in T1D and other immune-mediated disorders.

\section{Steady-state cell apoptosis and immune tolerance}

\subsection{Steady-state apoptosis}

The effective clearance of apoptotic cells and subsequent regeneration of cells is crucial in organ development, tissue homeostasis, response to injury, and maintenance of the innate and adaptive immune system (17). In the spleen and liver, greater than $1 \times 10^{11}$ circulating neutrophils are eliminated each day. The vast majority (95\%) of thymocytes die by apoptosis due to negative selection. Another example exists in the retina where photoreceptor rods continuously renew their light-sensitive outer segments (17). The reality is that almost every cell in our bodies is replaced during a lifetime, and some types of cells turnover more than once. It was once thought that clearance of apoptotic cells was immunologically inert, but we now know that the uptake of apoptotic cells by phagocytes can induce immunosuppression or tolerance (discussed in greater detail below). Interestingly, some pathogens (Plasmodium falciparum) and tumors exploit the immune inhibitory pathways involved in apoptotic cell clearance to aid in their survival and perseverance in the body (17). Cell death and the ensuing removal of dying cells by phagocytes can have profound regulatory effects on the immune system.

\subsection{Immature dendrite cells (DCs) and macrophages engulf apoptotic cells during tissue cell turnover}

The fate of hundreds of millions of apoptotic tissue cells that die each day is to be engulfed as quickly as possible by antigen-presenting cells, especially immature dendritic cells and macrophages. DCs distributed in the peripheral tissues are able to sense "find-me" signals elicited by the apoptotic cells (18-23). DCs migrate toward the dying cells then bind the apoptotic cells through recognition of "eat-me" signals on their surface (20; 22; 24-26). After phagocytosing apoptotic cells, DCs home to the T cell zone of local draining lymph nodes where they present self tissue antigens in a tolerogenic fashion to self antigen-reactive $T$ cells that have escaped from the thymus. The various mechanisms will be discussed in the following sections.

\subsection{Dendritic cells acquire a tolerogenic phenotype following phagocytosis of apoptotic cells}

DCs interact with apoptotic cells through specific receptors that can recognize molecules uniquely expressed on the apoptotic cell surface. Early studies demonstrated that DCs that had engulfed apoptotic cells were able to maintain an immature state as evidenced by low expression levels of major histocompatibility complex (MHC) molecules and co-stimulatory molecules such as CD80, CD86 (27; 28). More importantly, these DCs resisted maturation induction by lipopolysaccharide or CD40L. When these immature DCs presented antigens to the antigen-specific $\mathrm{T}$ cells, the latter became unresponsive to subsequent stimulation by 
the same antigens $(29 ; 30)$. The mechanisms underlying this process were unclear, but the recent discovery of TAM (Tyro-3-Axl-Mer) receptors on DCs or macrophages that specifically recognize ligands on apoptotic cells may help unravel the mystery (31). TAM receptors directly or indirectly interact with apoptotic cell surface molecules and work together with cytokines to transduce suppressive signals in DCs or macrophages (31). TAM receptors play important roles in regulating innate immunity, helping to avoid unwanted autoimmunity. It is worth mentioning here that DCs interacting with apoptotic cells may become immunogenic under certain circumstances $(32 ; 33)$. An elegant study demonstrated that DCs phagocytosing bacteria-infected apoptotic cells became fully mature, showing strong $\mathrm{T}$ cell stimulatory activity, and induced inflammatory Th17 cells; whereas, DCs that had engulfed non-infected apoptotic cells acquired tolerogenic properties, inducing Foxp3+ regulatory $\mathrm{T}$ cells (33). This study suggests that following phagocytosis of dead cells during infections or inflammatory conditions, DCs or other antigen-presenting cells may actually trigger activation of self-reactive T cells, which may lead to autoimmunity or autoimmune disorders. More details regarding immunogeneic and tolerogenic cell death were discussed recently (review by Green, et al) (32).

\subsection{TGF- $\beta$ is an important cytokine participating in immune tolerance induced by apoptotic cells}

Several cytokines produced during the clearance of apoptotic cells are associated with the induction of tolerance. In particular, TGF- $\beta$ is important in this process. TGF- $\beta$ is an immunosuppressive cytokine that can be produced by apoptotic cells but more importantly, is secreted by DCs or macrophages that have phagocytosed apoptotic cells (34-37). Recently, TGF- $\beta$ has been identified as an essential cytokine for the differentiation of adaptive Foxp3+ regulatory T cells (Tregs) $(38 ; 39)$. Tregs play an important role in maintaining peripheral tolerance (40). Thus, increased levels of TGF- $\beta$ produced during the processing of apoptotic cells likely contributes to apoptotic cell-induced tolerance through generation of Tregs. A recent report supplied evidence to support this idea by demonstrating that TGF- $\beta$ is essential for anti-CD3 antibody treatment-induced autoantigen-specific tolerance in experimental autoimmune encephalomyelitis (EAE) (41). In this report, the authors clearly demonstrated that macrophages ingesting apoptotic T cells produced high levels of TGF- $\beta$, which subsequently induced Treg production, and consequently, EAE was prevented. However, under conditions where DCs and macrophages were depleted, the effect of antiCD3 therapy was drastically compromised in preventing EAE because of the reduced levels of systemic TGF- $\beta$ and Tregs (41). Hence, the local or systemic levels of TGF- $\beta$ may be an important factor in determining the immunological outcomes associated with engulfment of apoptotic cells.

\subsection{Phosphatidylserine on apoptotic cells mediates immunosuppression}

The recognition of apoptotic cells by phagocytes involves highly specific receptor-ligand interactions. In the synapse between a phagocyte and an apoptotic cell, multiple Apoptotic Cell-Associated Molecular Patterns (ACMP) presented on the apoptotic cell surface interact with Pattern-Recognition Receptors (PRR) that are expressed by the phagocyte (42). One of the earliest events in apoptosis is the "flip-flop" and external exposure of the anionic phospholipid phosphatidylserine (PS), which is normally restricted to the inner leaflet of the plasma membrane. PS is an important "eat-me" signal that stimulates apoptotic cell 
phagocytosis by DCs or macrophages. PS recognition receptors can either bind PS directly or bind indirectly through soluble bridging molecules. Receptors that directly interact with PS include members of the TIM (T cell immunoglobulin domain and mucin domain) family (43-49), BAI1, the seven transmembrane brain angiogenesis inhibitor 1(50), and the atypical EGF-motif containing membrane protein Stabilin-2 (20). MFG-E8 has been identified as a bridging molecule that can simultaneously bind PS on apoptotic cells with high affinity (5154) and engage integrin av $\beta 3$ on phagocytes. Gas6 (growth arrest specific gene 6) and protein S bridge PS to TAM family of receptors on phagocytes (31). Additional membrane proteins important in binding apoptotic cells include CD36, CD14, CD68, and thrombospondins (55-58). It is believed that PS receptors not only help to physically tether the apoptotic cells to the phagocytes but also generate intracellular signals that stimulate endocytosis. Important for the induction of tolerance, binding of PS to its receptor MerTK on DCs or macrophages induces downstream signals which result in down-regulation of NF$\mathrm{kB}$ and inhibition of pro-inflammatory cytokine production (59-61). It has also been reported that PS through the bridging molecule Gas6 protein binds to AXL/Mer family members to suppress NK-kB activation and inflammatory mediators such as IL-1 and iNOS (62). Recently, it was shown monocyte-derived DCs incubated with PS liposomes assumed immature DC characteristics and were unable to stimulate T cells $(63 ; 64)$. Our data showed that water-soluble PS (C6) dramatically inhibited $\mathrm{T}$ cell proliferation in response to stimulatory anti-CD3 and anti-CD28 antibodies ( $\mathrm{Xia}$, unpublished data). We also discovered that PS could be released from apoptotic cells, as supernatants from apoptotic cells efficiently blocked anti-PS antibody binding to apoptotic cells (xia, unpublished data). Therefore, PS has proven to be an important factor in apoptotic cell-induced immunosuppression.

\section{3. $\beta$ cell apoptosis and type 1 diabetes pathogenesis}

It has been widely accepted that diabetes, including T1D and T2D, is associated with excess death of pancreatic $\beta$ cells. However, evidence that pancreatic $\beta$ cells undergo a wave of cell death in the early age of normal individuals suggests that early $\beta$ cell death may be beneficial for avoiding autoimmunity. In line with this, results from an animal study demonstrated that induction of $\beta$ cell death at an early age in NOD mice protected the animals from developing T1D (65). Despite contradictions, $\beta$ cell death may play distinct and different roles in autoimmune processes depending on the environment where $\beta$ cell death occurs. The following will discuss $\beta$ cell apoptosis and T1D pathogenesis in hopes of clarifying certain issues that are clouded in confusion.

\subsection{Two waves of $\beta$ cell death in T1D}

Animal studies have shown that pancreatic $\beta$ cells only undergo a single wave of $\beta$ cell death at an early age in normal strains of animals, whereas, in T1D prone animals, there are two waves of $\beta$ cell death. The first wave occurs at ages similar to normal strains, yet, the second wave of $\beta$ cell death follows a few weeks later $(66 ; 67)$. The second wave of $\beta$ cell death is thought to be mediated by autoimmune attack $(66 ; 68)$. However, it is still unclear whether the first wave of $\beta$ cell death is associated with the second wave, and why the second wave of $\beta$ cell death occurs only in T1D prone animals. A few lines of evidence show that inefficient processing of dead $\beta$ cells at an early age might contribute to the 
development of autoimmune responses in the pancreatic islets $(66 ; 67)$. Unfortunately, the role of early $\beta$ cell death in T1D pathogenesis remains poorly understood.

\section{$3.2 \beta$ cell death in self tolerance or autoimmunity}

While both environmental and genetic risk factors contribute to the susceptibility of an individual to T1D, the exact mechanisms that initiate T1D autoimmunity remain elusive (69). Accumulating evidence supports the idea that the exposure of $\beta$ cell antigens resulting from early $\beta$ cell death may be an initiating factor. If this is really the initiating factor, why does autoimmunity only occur in T1D prone animals but not in normal strains? As we discussed earlier, apoptotic cells are immediately processed by phagocytes in vivo in order to maintain self tolerance. A key in this process is the quick and efficient clearance of apoptotic cells after early stages of cell apoptosis, which prevents reactions to self-antigens. Otherwise, the apoptotic cells may advance to late stage apoptosis or to a necrotic stage at which point the dead cells may cause inflammatory responses and potentially lead to autoimmune disorders, such as SLE, as mentioned previously. It has been reported that in T1D animal models, phagocytes are defective in efficiently clearing apoptotic $\beta$ cells during the first wave of islet $\beta$ cell death (66). Failure to scavenge dead $\beta$ cells could potentially initiate $\beta$ cell antigen-specific autoimmunity, which subsequently leads to recruitment of additional inflammatory cells, including macrophages, DCs, and $\mathrm{T}$ cells to the islets to worsen autoimmune damage (68). This hypothesis, however, does not help explain the T1D protection mediated by streptozotocin-induced $\beta$ cell death in NOD mice at young ages (65). In the study reported by Hugues et al, the authors demonstrated that NOD mice were protected from developing T1D when they were treated at 4 weeks of age with streptozotocin to induce cell death of a limited number of $\beta$ cells (65). The data in the study also showed that there were more cells infiltrating the islets at an early time after streptozotocin administration, but the islet $\beta$ cells were eventually protected. These findings suggest that $\beta$ cell death induced by streptozotocin before autoimmunity begins may modulate autoimmune $\mathrm{T}$ cells to become tolerized, thereby protecting from T1D. The mechanisms underlying this protection were not well elucidated, but it is possible that early induction of $\beta$ cell death creates a microenvironment that is more tolerogenic and characterized by increased TGF- $\beta$ production by apoptotic $\beta$ cells or the DCs and macrophages that phagocytose them. A recent report demonstrated that expression of TGF$\beta$ on islet $\beta$ cells actually protected NOD mice from T1D (70), suggesting that local levels of TGF- $\beta$ may play an essential role in the protection of $\beta$ cells from autoimmune attack.

Regarding the relationship between $\beta$ cell death and T1D pathogenesis, more attention has been focused on the investigation as to how innate and adaptive immunity induces $\beta$ cell death leading to autoimmune diabetes. Based on histological analysis of the pancreas in T1D, DCs and macrophages appear first in the islets $(66 ; 68)$. Thus, it is believed that DCs and macrophages are two important inflammatory cells in the initiation of autoimmunity. DCs and macrophages not only damage $\beta$ cells directly through the secretion of proinflammatory cytokines such as TNF- $\alpha$, IL-1, and IL-6, but more importantly, they present $\beta$ cell antigens to antigen-specific CD4+ and CD8+ T cells, leading to adaptive autoimmune reactions against islet $\beta$ cells. Preferentially induced Th1 cells in T1D can target $\beta$ cells through direct killing or by secreting pro-inflammatory cytokines, such as IFN- $\gamma$ (71). CD8+ cytotoxic $\mathrm{T}$ cells may kill $\beta$ cells via the release of granzymes and perforin (72). Furthermore, soluble inflammatory mediators secreted by DCs, macrophages, or activated T 
cells, such as IL-1 and IFN- $\gamma$, can induce Fas expression on $\beta$ cells $(71 ; 73 ; 74)$. Pancreatic histology of new onset T1D patients has shown that Fas $+\beta$ cells are surrounded by FasL + activated T cells, (75-77) indicating that activated T cells may induce $\beta$ cell death through FasL-Fas ligation during $\mathrm{T}$ cell and $\beta$ cell interaction. There is still some debate about whether the up-regulation of Fas on $\beta$ cells is associated with $\beta$ cell death. Specific deletion of Fas from $\beta$ cells using Cre-Loxp genetic manipulation leads to normal or slightly reduced incidence of T1D (78). Similar results were obtained with $\beta$ cells over-expressing a dominant negative form of Fas (79). Another important factor potentially involved in $\beta$ cell death is oxidative stress occurring in $\beta$ cells during active inflammation in the local islets. It has been documented that $\beta$ cells are highly sensitive to oxidative stress because of their inefficiency in making antioxidants (80-82). Streptozotocin and alloxan drug-induced diabetes is thought to be due to overproduction of reactive oxygen species (ROS) induced by the drugs. Supporting the role of ROS in $\beta$ cell death, a study showed that genetic overexpression of the antioxidant thioredoxin in $\beta$ cells significantly prevented NOD mice from developing T1D (83). Overexpression of antioxidants such as catalase or metallothionein reduces the susceptibility of $\beta$ cells to cytokine-induced death in vitro (84-86). Recently, it was demonstrated that ROS participated in inflammatory processes by activating inflammatory cytokines via inflammasome-dependent or inflammasome-independent pathways $(87 ; 88)$. Inflammatory cytokines such as IL-1 are secondary to oxidative stress and exaggerate $\beta$ cell damage. Based on what has been described above, it is likely that T1D is a disease caused by multiple factors working together. Once autoimmunity starts, a vicious cycle appears to be initiated until all $\beta$ cells are destroyed, leading to diabetes.

In summary, $\beta$ cell death can play completely opposing roles in T1D pathogenesis. Steadystate $\beta$ cell death that occurs in normal individuals, normal strains of mice or young T1Dprone animals provides protection from T1D. On the other hand, $\beta$ cell death that occurs under inflammatory conditions seems to accelerate disease progression through exaggerating inflammation. Therefore, any measures capable of breaking this vicious cycle will potentially offer opportunities to restore homeostasis, facilitate self tolerance, and hopefully attenuate or cure T1D.

\section{Application of apoptotic cells in immune-mediated disorders}

\subsection{Extracorporeal photopheresis for the treatment of autoimmune disease}

Intravenous delivery of apoptotic cells has been shown to have clinical efficacy in T-cell mediated autoimmune diseases. Extracorporeal photopheresis (ECP) is a novel immunotherapy that involves collecting peripheral blood mononuclear cells from patients and exposing them to a photoactivatable drug that induces programmed cell death or apoptosis. More specifically, the apheresis-based procedure involves connecting a patient through venous access to the THERAKOSTM UVAR ${ }^{\mathrm{TM}}$ XTSTM or CELLEXTM photopheresis medical device (shown below). Both photopheresis systems offer a point-of-care, patient connected, sterile, automated centrifugation platform that separates white blood cells from whole blood (89). Once white blood cells are concentrated into a collection bag, 8methoxypsoralen (8-MOP), a naturally derived furocoumarin compound that readily intercalates into DNA (trade name $=\mathrm{UVADEX}^{\circledR}$ ), is added and readily absorbs into the cells. 8-MOP-treated cells are then circulated across a photoactivation plate, which is exposed to 1.5-2 Joules $/ \mathrm{cm}^{2}$ of energy from an ultraviolet A (UVA) light source (90). Apoptotic processes are triggered in the treated cells, and they are returned to the patient. ECP is 
currently approved by the U.S. Food and Drug Administration for the palliative treatment of skin manifestations associated with Cutaneous $\mathrm{T}$ cell Lymphoma (CTCL) that is refractory to other forms of therapy. ECP is available worldwide (>150 medical centers) (91) and has been utilized for over 20 years for the treatment of both allo-immune (graft vs host disease, GVHD, and graft rejection) and autoimmune conditions (Crohn's disease, T1D). This therapy is associated with a very rare incidence of serious adverse events and is generally well-tolerated by patients with no significant side effects (90; 92). In a few European countries, an alternative method has been utilized for performing photopheresis. Mononuclear cells are collected with a standard cell separator and UVA irradiation is performed in a laboratory setting using a stand-alone irradiator; however, no commercially available UVA irradiator is compliant with European standards marking for the sale and use of medical devices for performing ECP. While there are chain-of-custody issues and potential risks of infection associated with these 'open' photopheresis systems, there are reports of similar clinical efficacy between both techniques; however, no head-to-head comparison studies have been reported to date (93).

ECP is most commonly used to treat CTCL and GVHD. CTCL is a rare lymphoproliferative disorder characterized by the accumulation of malignant $\mathrm{T}$ lymphocytes in the skin. While clinicians have been successfully treating some CTCL patients with ECP monotherapy (94), others use ECP in combination with other therapies to improve outcomes (92). On average, response rates in CTCL range from $33 \%$ to $88 \%$ with ECP monotherapy; whereas, multimodality ECP response rates are comparable (94). Collectively across 19 studies, a combined overall response rate of $55.7 \%$ was reported across all stages of CTCL with $17.6 \%$ achieving a complete response (95). ECP is also highly beneficial for the treatment of GVHD. In a prospective phase II study involving steroid-refractory acute GVHD patients, $82 \%$ of patients with cutaneous involvement, $61 \%$ with liver involvement, and $61 \%$ with gut involvement achieved responses after ECP treatments. Interestingly, ECP not only facilitated tapering and eventual discontinuation of corticosteroids in responders but ECP therapy also improved overall survival $(96 ; 97)$. A retrospective analysis of 71 patients with severe chronic GVHD demonstrated that patients who had received ECP showed an overall response rate of $61 \%$, and complete responses were observed in $20 \%$ of patients (98). ECP therapy has also been reported to provide positive clinical outcomes for the treatment of rejection episodes associated with cardiac and lung transplantation (99). In conclusion, published data demonstrate that patients with conditions characterized by overactive inflammation and dysregulation of $\mathrm{T}$ cells can realize significant clinical benefit from ECP treatments. ECP seems to restore immune homeostasis without causing general immunosuppression in patients with inflammatory diseases. In fact, ECP-treated patients can respond normally to novel and recall antigenic challenges (100).

\subsection{Apoptotic cell infusion and the use of ECP in type 1 diabetes}

Intravenous infusion of apoptotic cells can significantly prevent type 1 diabetes in non-obese diabetic mice (101-103). More specifically, weekly delivery of ECP-treated spleen cells significantly delayed the onset of diabetes. The disease protective effects were enhanced when apoptotic cells were injected in combination with $\beta$ cell antigens as demonstrated by a reduction in insulitis and an increase in Foxp3+ Treg cells. Importantly, infusion of ECPtreated spleen cells did not induce global immunosuppression or exacerbate autoimmune responses in treated mice (101). 


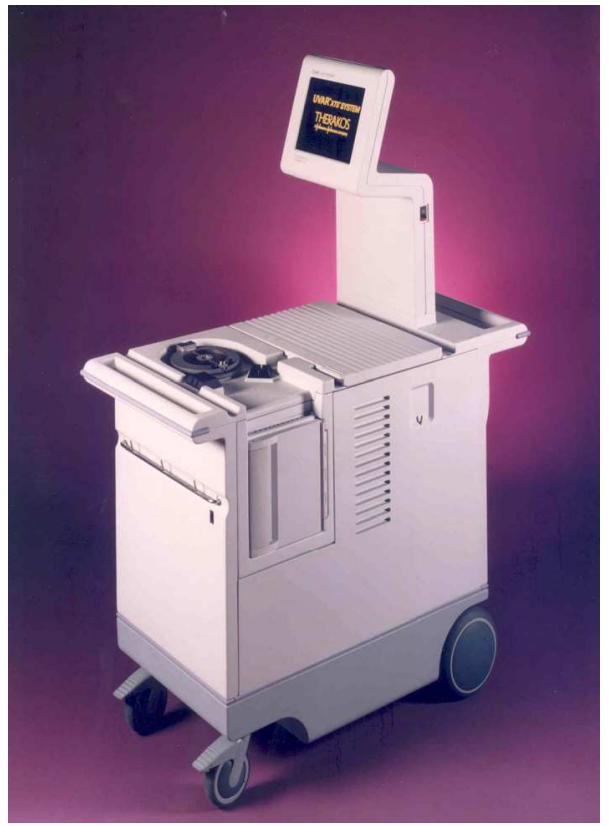

Fig. 1. THERAKOSTM XTSTM Photopheresis instrument

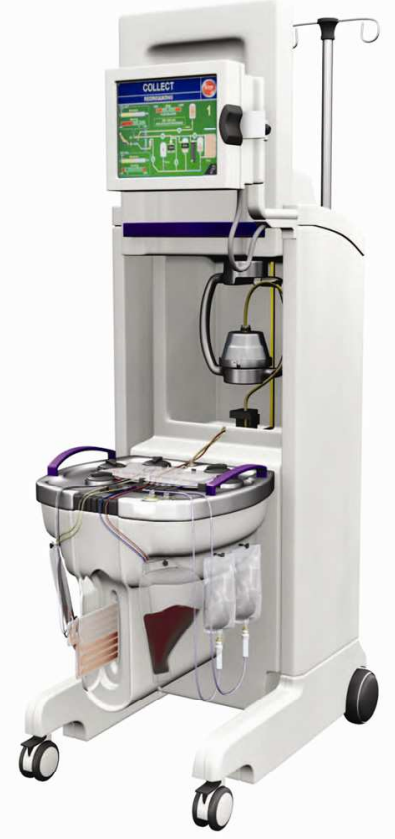

Fig. 2. THERAKOSTM CELLEXTM Photopheresis Instrument 
In the clinical setting, positive outcomes have been reported when ECP was used to treat patients with various autoimmune diseases. For instance, ECP has positively modified the disease course in systemic sclerosis, rheumatoid arthritis, atopic dermatitis, and systemic lupus erythematosus due to its ability to modulate immune processes (104). Because T1D is an immune-mediated disease with a defined diagnosis that follows a relatively homogeneous course, Ludvigsson et al (105) conducted a double-blind, randomized, placebo-controlled, prospective study to assess the efficacy of ECP in children newly diagnosed with Type 1 diabetes. A total of 49 patients were enrolled in the study across 3 different pediatric sites in Sweden. A total of 19 kids completed treatment in the active ECP treatment group; whereas, 21 patients completed treatment in the control group. Photopheresis was delivered using the first-generation THERAKOSTM UVAR photopheresis system in combination with an oral formulation of 8-MOP. ECP or sham pheresis was delivered on 2 consecutive days with the first treatment given within 5-6 days after the initial clinical diagnosis, and treatments were repeated after 2, 4, 8 and 12 weeks so that a total of 10 treatments were delivered over a 3 month period. The patients were followed for at least 3 years. Blood glucose levels, $\mathrm{C}$ peptide, $\mathrm{HbA1c}$ values, and other blood measures were monitored throughout the treatment period as well as during follow-up. Results demonstrate that the group actively treated with ECP had higher $\mathrm{C}$ peptide concentrations in the urine during the follow up period compared to the control group. Regarding $\mathrm{HbA1c}$ values, the proportion of children with $\mathrm{HbA1c}<6 \%$ was similar in the two groups during the follow up period. Interestingly, insulin doses $/ \mathrm{kg}$ body weight required for stable blood glucose levels were always lower in the ECP-treated group, except at month 1 when photopheresis treatments were just beginning. The control group was more seriously ill than the ECP group with more weight loss, more ketonuria, higher $\mathrm{HbA1c}$ values and lower $\mathrm{pH}$, which provides additional support for the efficacy of ECP in Type 1 diabetes. Collectively, the results from this study show that ECP had a long-term effect on the disease processes associated with diabetes in children, and there was a low frequency of adverse events associated with ECP procedures in this study. While it cannot be argued that the effectiveness of ECP was lower compared to other immune response modifiers, the safety profile of this modality does make it an attractive candidate for treating children with T1D. Since the study was conducted, there have been advances in the formulation of 8-MOP, advances in photopheresis device technology, and advances in the understanding of treatment algorithms and of the mechanism of action of ECP. As a result, additional studies are warranted to determine the optimal utilization of this treatment modality in order to reach its full potential in the T1D clinical setting.

\subsection{ECP therapy in rheumatoid arthritis}

A pilot study was conducted at Yale University by Malawista et al to investigate the effect of ECP on rheumatoid arthritis (RA) (106). Seven RA patients were treated on 2 consecutive days with ECP at 4 week intervals for 6 months. Joint scores and counts improved in 4 patients after 3 to 4 months of therapy. Responses were maintained for 2 to 3 months after completion of the protocol and no serious or toxic adverse events were reported (106). In a single-blinded, controlled, parallel group multicenter phase III clinical trial, the effect of ECP on joint count, joint score, bilateral grip strength, and physician assessment were compared to treatment with gold. In all categories, the 17 patients treated with ECP showed improvement over the 11 
patients treated with gold. Univariate analysis of the results suggests that ECP treated patients responded in a comparable fashion to patients treated with gold $(107 ; 108)$.

\subsection{ECP therapy in crohn's disease}

Crohn's disease (CD) and ulcerative colitis (UC) are collectively known as inflammatory bowel disease (IBD) and are chronic inflammatory conditions affecting the gastrointestinal tract in which seemingly innocuous luminal antigens stimulate mucosal $\mathrm{CD}^{+} \mathrm{T}$ cell mediated autoimmune responses in genetically susceptible individuals (109). A delicate balance of inflammation involving pro-inflammatory cytokines (TNF-a, IL-1, IL-6, IL-8, and IL-12) and anti-inflammatory cytokines (IL-4, IL-10, IL-11, and IL-13) occurs at the intestinal mucosa under normal conditions; however, once that balance is perturbed, chronic inflammation characterized by persistent $\mathrm{T}$ cell activation ensues. Current treatment guidelines recommend the use of aminosalicylates, glucocorticosteroids, and immunomodulators (azathioprine, 6mercaptopurine, cyclosporine) to treat $\mathrm{UC}$ and $\mathrm{CD}$; however, these medical approaches have limitations in efficacy and safety (110). Emerging therapeutic interventions targeting immunopathogenic mechanisms in CD include anti-TNF biologic therapies (eg. infliximab, etanercept, and adalimumab), inhibitors of proinflammatory cytokine receptors (anti-IL-6R), and anti-leukocyte adhesion therapies (natalizumab); however, long term safety still needs to be fully evaluated (110). Because of its safety and effectiveness in diseases mediated by pathogenic T cell populations, ECP has also been used to treat Crohn's disease.

Reinisch et al (111) reported results from a prospective, open label, single center pilot study conducted in 10 patients to assess the efficacy of ECP in the treatment of steroid-dependent Crohn's disease. Response was observed in 8 of 10 patients after a median time of 10 weeks (range 8-19 weeks), and remission was seen in 4 of these patients after a median time of 20 weeks (range 19-23 weeks). Steroid maintenance doses were significantly reduced from baseline, and improvements in clinical performance and quality of life were observed in responding patients. Mean C-reactive protein (CRP) declined and intestinal permeability in patients with ileal and ileocolonic Crohn's disease decreased after ECP.

Recently, a phase II study investigating ECP in 28 patients with moderately active CD who were refractory or intolerant to immunosuppressants and/or anti-TNF agents was completed (112). ECP was performed twice weekly for 4 weeks then twice weekly every other week until week 12. Primary efficacy assessment was a decrease in Crohn's Disease Activity Index (CDAI) of $>100$ from baseline or CDAI $<150$ at week 12 . A clinical response was obtained in 14 of $28(50 \%)$ patients, 13 of whom responded by week 6 . Remission was observed in 7 of 28 patients who also had a CDAI reduction of over 200 points. Seven of 14 patients who were intolerant or refractory to anti-TNF agents responded to ECP. ECP was well-tolerated with minor serious adverse events reported. The investigators concluded that ECP is safe and beneficial for patients with moderately active Crohn's Disease that is refractory to immunosuppression and/or anti-TNF therapies.

\subsection{ECP therapy in other autoimmune conditions}

In pilot studies, patients with atopic dermatitis, multiple sclerosis, pemphigus vulgaris, and systemic sclerosis have acheived promising results when treated with ECP (92); however, further investigation through large, prospective clinical studies is required in order to fully understand the utility of this complex therapeutic approach in treating autoimmune conditions. 


\section{Immunological consequences of apoptotic cell clearance}

\subsection{Apoptotic cells modulate dendritic cell function}

To limit unnecessary collateral damage in healthy tissue, apoptotic cells are rapidly and efficiently removed or cleared by both professional (dendritic cells and macrophages) and non-professional (cells localized near the dying cell, eg., primary lens epithelial cells, astrocytes, microglia) phagocytes (113). As mentioned previously, apoptotic cells can potentially be immunogenic and prime immune responses. In this section, we will only focus on the role of apoptotic cells in the induction of tolerance.

Apoptotic cell clearance plays a critical role in the maintenance of central and peripheral selftolerance because 1) removal of cell corpses prevents the release of potentially immunogenic intracellular materials from dying cells and 2) phagocytes present self-antigens derived from apoptotic cells to T cells in the draining lymph nodes, which leads to deletion or anergy of selfreactive T cells. Dendritic cells, in particular, play an important role in these ongoing selftolerance mechanisms (114). While there are several factors involved in the induction of immunological tolerance, the generation of regulatory $\mathrm{T}$ cells by DCs that have ingested apoptotic cells is a critical aspect of peripheral self-tolerance (115-117).

Apoptotic cells exert immunosuppressive effects when they are engulfed by phagocytes by modulating cytokine secretion profiles, blocking maturation, and inducing Tregs (118). Voll et al (119) were the first to report that the presence of apoptotic cells during monocyte activation increases the ability of these cells to secrete anti-inflammatory cytokines (IL-10) and decreases their ability to release pro-inflammatory cytokines (TNF-a, IL-1, and IL-12). Our data demonstrate similar results can be obtained in vitro when human monocyte-derived dendritic cells are incubated with ECP-treated cells prior to or during activation (unpublished data). In a mouse model of allogeneic bone marrow engraftment, intravenous infusion of apoptotic cells exerted their immunoregulatory functions through TGF- $\beta$ dependent Treg induction which required host macrophages $(34 ; 41)$. In fact, TGF- $\beta$ is mostly responsible for the immunomodulatory effects of apoptotic cells by creating a suppressive microenvironment (34; 120-122). Not only do apoptotic cells regulate TGF- $\beta$ secretion but engulfment of apoptotic neutrophils has been shown to reduce the ability of DCs to secrete IL-23 (123), which is involved in the differentiation of Th17 lymphocytes and may reciprocally affect Treg cell expansion (124). In addition to modulating cytokine production, engulfment of apoptotic cells reduces the ability of DCs to stimulate effector immune responses by decreasing the levels of co-stimulatory surface molecule expression and by inhibiting maturation even after an inflammatory challenge. In humans, Lamioni et al showed that the apoptotic leukocytes are cleared by antigen-presenting cells in vivo leading to the differentiation of antigen-presenting cells towards a more tolerogenic phenotype (125). Collectively, evidence suggests that upon engagement and engulfment of apoptotic cells, there is an increase in anti-inflammatory cytokines, a reduction of pro-inflammatory cytokines, and a diminution in the stimulatory capacity by APCs, which results in suppression of inflammation and cell-mediated immunity, eliciting immune tolerance (89).

\subsection{Apoptotic cell infusion leads to the generation of regulatory $\mathrm{T}$ cells}

Regulatory $\mathrm{T}$ lymphocytes play a critical role in self-tolerance and homeostasis by actively suppressing immune responses (126-128). In the periphery, Tregs are present as either naturally occurring or induced, and the classic Treg phenotype is CD4+CD25+ cells expressing the molecular marker Foxp3, which is a member of the forkhead/winged-helix 
family of transcriptional regulators (129). There is evidence in both animal models and from clinical studies that apoptotic cell infusion induces Tregs. Wang et al showed that the survival of cardiac allografts was prolonged as a result of donor apoptotic cell infusion which induced Tregs (130). In another mouse model of cardiac allograft rejection, George et al showed that compared to untreated mice, the frequency of splenic CD4+CD25+Foxp3+ cells increased 2-fold in ECP-treated animals and graft survival was prolonged (131). In a murine model of contact hypersensitivity, Maeda et al demonstrated that intravenous infusion of ECP-treated leukocytes induced Tregs (132). These Tregs were shown to mediate suppression through IL-10 and were characterized as expressing glucocorticoid-induced TNF family-related receptor (GITR) and the surface molecule neuropilin-1 (133). In a murine model that closely reproduces the treatment of GVHD with ECP, the infusion of ECPtreated cells significantly reduced clinical GVHD scores and pathology, diminished mortality, and increased the number of Foxp3+ Tregs in the spleen and thymus (134) . Extending pre-clinical findings to humans, Lamioni et al observed that ECP treatments promote a significant increase in regulatory $\mathrm{T}$ cells in the blood of cardiac and lung transplant patients compared to untreated healthy individuals and patients who received traditional immunosuppressants (125). Treg function in both GVHD and CTCL patients was reported to be strengthened as a result of ECP treatments (135). The frequency of circulating CD4+CD25+GITR+CD62L+Foxp3+ Tregs with suppressive function increased in GVHD patients treated with ECP, suggesting an association between elevation in Tregs and response to ECP treatments (136). Lastly, a recent report from the pediatric ECP T1D trial suggested that ECP effectively inhibited autoimmune processes against islet cells by maintaining regulatory $\mathrm{T}$ cell activity (137). Collectively, these results suggest that infusion of apoptotic cells or ECP treatments can mediate an upregulation of Tregs via modulation of cytokines and dendritic cells, which may help explain why ECP has therapeutic effects in malignancy, alloimmune conditions, and autoimmunity; however, additional research and clinical studies are warranted in order to fully understand the full potential of apoptotic cells in the treatment of diseases.

\section{References}

[1] Borus JS, Laffel L: Adherence challenges in the management of type 1 diabetes in adolescents: prevention and intervention. Curr Opin Pediatr 22:405-411, 2010

[2] Hood KK, Rohan JM, Peterson CM, Drotar D: Interventions with adherence-promoting components in pediatric type 1 diabetes: meta-analysis of their impact on glycemic control. Diabetes Care 33:1658-1664, 2010

[3] Fasanmade OA, Odeniyi IA, Ogbera AO: Diabetic ketoacidosis: diagnosis and management. Afr J Med Med Sci 37:99-105, 2008

[4] Umpierrez GE, Kitabchi AE: Diabetic ketoacidosis: risk factors and management strategies. Treat Endocrinol 2:95-108, 2003

[5] Weber C, Kocher S, Neeser K, Joshi SR: Prevention of diabetic ketoacidosis and selfmonitoring of ketone bodies: an overview. Curr Med Res Opin 25:1197-1207, 2009

[6] Ritz E, Haxsen V: Diabetic nephropathy and anaemia. Eur J Clin Invest 35 Suppl 3:66-74, 2005

[7] Toto RD: Heart disease in diabetic patients. Semin Nephrol 25:372-378, 2005

[8] Pop-Busui R, Roberts L, Pennathur S, Kretzler M, Brosius FC, Feldman EL: The management of diabetic neuropathy in CKD. Am J Kidney Dis 55:365-385, 2010 
[9] Alicic RZ, Tuttle KR: Management of the diabetic patient with advanced chronic kidney disease. Semin Dial 23:140-147, 2010

[10] Wasserfall $\mathrm{CH}$, Atkinson MA: Autoantibody markers for the diagnosis and prediction of type 1 diabetes. Autoimmun Rev 5:424-428, 2006

[11] Shoda LK, Young DL, Ramanujan S, Whiting CC, Atkinson MA, Bluestone JA, Eisenbarth GS, Mathis D, Rossini AA, Campbell SE, Kahn R, Kreuwel HT: A comprehensive review of interventions in the NOD mouse and implications for translation. Immunity 23:115-126, 2005

[12] Atkinson MA, Eisenbarth GS: Type 1 diabetes: new perspectives on disease pathogenesis and treatment. Lancet 358:221-229, 2001

[13] Sakaguchi S, Ono M, Setoguchi R, Yagi H, Hori S, Fehervari Z, Shimizu J, Takahashi T, Nomura T: Foxp3+ CD25+ CD4+ natural regulatory $\mathrm{T}$ cells in dominant selftolerance and autoimmune disease. Immunol Rev 212:8-27, 2006

[14] Parish IA, Heath WR: Too dangerous to ignore: self-tolerance and the control of ignorant autoreactive T cells. Immunol Cell Biol 86:146-152, 2008

[15] Licht R, Dieker JW, Jacobs CW, Tax WJ, Berden JH: Decreased phagocytosis of apoptotic cells in diseased SLE mice. J Autoimmun 22:139-145, 2004

[16] Gaipl US, Voll RE, Sheriff A, Franz S, Kalden JR, Herrmann M: Impaired clearance of dying cells in systemic lupus erythematosus. Autoimmun Rev 4:189-194, 2005

[17] Erwig LP, Henson PM: Immunological consequences of apoptotic cell phagocytosis. Am J Pathol 171:2-8, 2007

[18] Mueller RB, Sheriff A, Gaipl US, Wesselborg S, Lauber K: Attraction of phagocytes by apoptotic cells is mediated by lysophosphatidylcholine. Autoimmunity 40:342-344, 2007

[19] Lauber K, Blumenthal SG, Waibel M, Wesselborg S: Clearance of apoptotic cells: getting rid of the corpses. Mol Cell 14:277-287, 2004

[20] Ravichandran KS: Find-me and eat-me signals in apoptotic cell clearance: progress and conundrums. J Exp Med 207:1807-1817, 2010

[21] Peter C, Waibel M, Radu CG, Yang LV, Witte ON, Schulze-Osthoff K, Wesselborg S, Lauber K: Migration to apoptotic "find-me" signals is mediated via the phagocyte receptor G2A. J Biol Chem 283:5296-5305, 2008

[22] Elliott MR, Chekeni FB, Trampont PC, Lazarowski ER, Kadl A, Walk SF, Park D, Woodson RI, Ostankovich M, Sharma P, Lysiak JJ, Harden TK, Leitinger N, Ravichandran KS: Nucleotides released by apoptotic cells act as a find-me signal to promote phagocytic clearance. Nature 461:282-286, 2009

[23] Chekeni FB, Elliott MR, Sandilos JK, Walk SF, Kinchen JM, Lazarowski ER, Armstrong AJ, Penuela S, Laird DW, Salvesen GS, Isakson BE, Bayliss DA, Ravichandran KS: Pannexin 1 channels mediate 'find-me' signal release and membrane permeability during apoptosis. Nature 467:863-867, 2010

[24] Gardai SJ, Bratton DL, Ogden CA, Henson PM: Recognition ligands on apoptotic cells: a perspective. J Leukoc Biol 79:896-903, 2006

[25] Grimsley C, Ravichandran KS: Cues for apoptotic cell engulfment: eat-me, don't eat-me and come-get-me signals. Trends Cell Biol 13:648-656, 2003

[26] Ravichandran KS: "Recruitment signals" from apoptotic cells: invitation to a quiet meal. Cell 113:817-820, 2003

[27] Inaba K, Turley S, Yamaide F, Iyoda T, Mahnke K, Inaba M, Pack M, Subklewe M, Sauter B, Sheff D, Albert M, Bhardwaj N, Mellman I, Steinman RM: Efficient 
presentation of phagocytosed cellular fragments on the major histocompatibility complex class II products of dendritic cells. J Exp Med 188:2163-2173, 1998

[28] Steinman RM, Turley S, Mellman I, Inaba K: The induction of tolerance by dendritic cells that have captured apoptotic cells. J Exp Med 191:411-416, 2000

[29] Clayton AR, Prue RL, Harper L, Drayson MT, Savage CO: Dendritic cell uptake of human apoptotic and necrotic neutrophils inhibits CD40, CD80, and CD86 expression and reduces allogeneic $\mathrm{T}$ cell responses: relevance to systemic vasculitis. Arthritis Rheum 48:2362-2374, 2003

[30] Kushwah R, Wu J, Oliver JR, Jiang G, Zhang J, Siminovitch KA, Hu J: Uptake of apoptotic DC converts immature DC into tolerogenic DC that induce differentiation of Foxp3+ Treg. Eur J Immunol 40:1022-1035, 2010

[31] Lemke G, Rothlin CV: Immunobiology of the TAM receptors. Nat Rev Immunol 8:327336, 2008

[32] Green DR, Ferguson T, Zitvogel L, Kroemer G: Immunogenic and tolerogenic cell death. Nat Rev Immunol 9:353-363, 2009

[33] Torchinsky MB, Garaude J, Martin AP, Blander JM: Innate immune recognition of infected apoptotic cells directs T(H)17 cell differentiation. Nature 458:78-82, 2009

[34] Kleinclauss F, Perruche S, Masson E, de Carvalho Bittencourt M, Biichle S, Remy-Martin JP, Ferrand C, Martin M, Bittard H, Chalopin JM, Seilles E, Tiberghien P, Saas P: Intravenous apoptotic spleen cell infusion induces a TGF-beta-dependent regulatory T-cell expansion. Cell Death Differ 13:41-52, 2006

[35] Zhang M, Xu S, Han Y, Cao X: Apoptotic cells attenuate fulminant hepatitis by priming Kupffer cells to produce interleukin-10 through membrane-bound TGF-beta. Hepatology 53:306-316, 2011

[36] Nacu N, Luzina IG, Highsmith K, Lockatell V, Pochetuhen K, Cooper ZA, Gillmeister MP, Todd NW, Atamas SP: Macrophages produce TGF-beta-induced (beta-ig-h3) following ingestion of apoptotic cells and regulate MMP14 levels and collagen turnover in fibroblasts. J Immunol 180:5036-5044, 2008

[37] Hodge S, Hodge G, Flower R, Reynolds PN, Scicchitano R, Holmes M: Up-regulation of production of TGF-beta and IL-4 and down-regulation of IL-6 by apoptotic human bronchial epithelial cells. Immunol Cell Biol 80:537-543, 2002

[38] Curotto de Lafaille MA, Lafaille JJ: Natural and adaptive foxp3+ regulatory T cells: more of the same or a division of labor? Immunity 30:626-635, 2009

[39] Horwitz DA, Zheng SG, Gray JD: Natural and TGF-beta-induced Foxp3(+)CD4(+) $\mathrm{CD} 25(+)$ regulatory $\mathrm{T}$ cells are not mirror images of each other. Trends Immunol 29:429-435, 2008

[40] Sakaguchi S, Yamaguchi T, Nomura T, Ono M: Regulatory T cells and immune tolerance. Cell 133:775-787, 2008

[41] Perruche S, Zhang P, Liu Y, Saas P, Bluestone JA, Chen W: CD3-specific antibodyinduced immune tolerance involves transforming growth factor-beta from phagocytes digesting apoptotic T cells. Nat Med 14:528-535, 2008

[42] Morelli AE, Larregina AT: Apoptotic cell-based therapies against transplant rejection: role of recipient's dendritic cells. Apoptosis 15:1083-1097, 2010

[43] Kobayashi N, Karisola P, Pena-Cruz V, Dorfman DM, Jinushi M, Umetsu SE, Butte MJ, Nagumo H, Chernova I, Zhu B, Sharpe AH, Ito S, Dranoff G, Kaplan GG, Casasnovas JM, Umetsu DT, Dekruyff RH, Freeman GJ: TIM-1 and TIM-4 glycoproteins bind phosphatidylserine and mediate uptake of apoptotic cells. Immunity 27:927-940, 2007 
[44] Miyanishi M, Tada K, Koike M, Uchiyama Y, Kitamura T, Nagata S: Identification of Tim4 as a phosphatidylserine receptor. Nature 450:435-439, 2007

[45] Santiago C, Ballesteros A, Martinez-Munoz L, Mellado M, Kaplan GG, Freeman GJ, Casasnovas JM: Structures of T cell immunoglobulin mucin protein 4 show a metalIon-dependent ligand binding site where phosphatidylserine binds. Immunity 27:941-951, 2007

[46] Santiago C, Ballesteros A, Tami C, Martinez-Munoz L, Kaplan GG, Casasnovas JM: Structures of T Cell immunoglobulin mucin receptors 1 and 2 reveal mechanisms for regulation of immune responses by the TIM receptor family. Immunity 26:299310, 2007

[47] Ichimura T, Asseldonk EJ, Humphreys BD, Gunaratnam L, Duffield JS, Bonventre JV: Kidney injury molecule- 1 is a phosphatidylserine receptor that confers a phagocytic phenotype on epithelial cells. J Clin Invest 118:1657-1668, 2008

[48] DeKruyff RH, Bu X, Ballesteros A, Santiago C, Chim YL, Lee HH, Karisola P, Pichavant M, Kaplan GG, Umetsu DT, Freeman GJ, Casasnovas JM: T cell/transmembrane, Ig, and mucin-3 allelic variants differentially recognize phosphatidylserine and mediate phagocytosis of apoptotic cells. J Immunol 184:1918-1930, 2010

[49] Wong K, Valdez PA, Tan C, Yeh S, Hongo JA, Ouyang W: Phosphatidylserine receptor Tim-4 is essential for the maintenance of the homeostatic state of resident peritoneal macrophages. Proc Natl Acad Sci U S A 107:8712-8717, 2010

[50] Park D, Tosello-Trampont AC, Elliott MR, Lu M, Haney LB, Ma Z, Klibanov AL, Mandell JW, Ravichandran KS: BAI1 is an engulfment receptor for apoptotic cells upstream of the ELMO/Dock180/Rac module. Nature 450:430-434, 2007

[51] Hanayama R, Tanaka M, Miwa K, Shinohara A, Iwamatsu A, Nagata S: Identification of a factor that links apoptotic cells to phagocytes. Nature 417:182-187, 2002

[52] Hanayama R, Tanaka M, Miyasaka K, Aozasa K, Koike M, Uchiyama Y, Nagata S: Autoimmune disease and impaired uptake of apoptotic cells in MFG-E8-deficient mice. Science 304:1147-1150, 2004

[53] Hanayama R, Tanaka M, Miwa K, Nagata S: Expression of developmental endothelial locus-1 in a subset of macrophages for engulfment of apoptotic cells. J Immunol 172:3876-3882, 2004

[54] Miyasaka K, Hanayama R, Tanaka M, Nagata S: Expression of milk fat globule epidermal growth factor 8 in immature dendritic cells for engulfment of apoptotic cells. Eur J Immunol 34:1414-1422, 2004

[55] Savill J, Hogg N, Haslett C: Macrophage vitronectin receptor, CD36, and thrombospondin cooperate in recognition of neutrophils undergoing programmed cell death. Chest 99:6S-7S, 1991

[56] Balasubramanian K, Schroit AJ: Characterization of phosphatidylserine-dependent beta2-glycoprotein I macrophage interactions. Implications for apoptotic cell clearance by phagocytes. J Biol Chem 273:29272-29277, 1998

[57] Imachi H, Murao K, Hiramine C, Sayo Y, Sato M, Hosokawa H, Ishida T, Kodama T, Quehenberger O, Steinberg D, Takahara J: Human scavenger receptor B1 is involved in recognition of apoptotic thymocytes by thymic nurse cells. Lab Invest 80:263-270, 2000

[58] Mevorach D: Opsonization of apoptotic cells. Implications for uptake and autoimmunity. Ann N Y Acad Sci 926:226-235, 2000 
[59] Eken C, Martin PJ, Sadallah S, Treves S, Schaller M, Schifferli JA: Ectosomes released by polymorphonuclear neutrophils induce a MerTK-dependent anti-inflammatory pathway in macrophages. J Biol Chem 285:39914-39921, 2010

[60] Wallet MA, Sen P, Flores RR, Wang Y, Yi Z, Huang Y, Mathews CE, Earp HS, Matsushima G, Wang B, Tisch R: MerTK is required for apoptotic cell-induced T cell tolerance. J Exp Med 205:219-232, 2008

[61] Yi Z, Li L, Matsushima GK, Earp HS, Wang B, Tisch R: A novel role for c-Src and STAT3 in apoptotic cell-mediated MerTK-dependent immunoregulation of dendritic cells. Blood 114:3191-3198, 2009

[62] Grommes C, Lee CY, Wilkinson BL, Jiang Q, Koenigsknecht-Talboo JL, Varnum B, Landreth GE: Regulation of microglial phagocytosis and inflammatory gene expression by Gas6 acting on the Axl/Mer family of tyrosine kinases. J Neuroimmune Pharmacol 3:130-140, 2008

[63] Shi D, Fu M, Fan P, Li W, Chen X, Li C, Qi X, Gao T, Liu Y: Artificial phosphatidylserine liposome mimics apoptotic cells in inhibiting maturation and immunostimulatory function of murine myeloid dendritic cells in response to 1-chloro-2,4-dinitrobenze in vitro. Arch Dermatol Res 299:327-336, 2007

[64] Chen X, Doffek K, Sugg SL, Shilyansky J: Phosphatidylserine regulates the maturation of human dendritic cells. J Immunol 173:2985-2994, 2004

[65] Hugues S, Mougneau E, Ferlin W, Jeske D, Hofman P, Homann D, Beaudoin L, Schrike C, Von Herrath M, Lehuen A, Glaichenhaus N: Tolerance to islet antigens and prevention from diabetes induced by limited apoptosis of pancreatic beta cells. Immunity 16:169-181, 2002

[66] O'Brien BA, Harmon BV, Cameron DP, Allan DJ: Apoptosis is the mode of beta-cell death responsible for the development of IDDM in the nonobese diabetic (NOD) mouse. Diabetes 46:750-757, 1997

[67] Maree AF, Kublik R, Finegood DT, Edelstein-Keshet L: Modelling the onset of Type 1 diabetes: can impaired macrophage phagocytosis make the difference between health and disease? Philos Transact A Math Phys Eng Sci 364:1267-1282, 2006

[68] Turley S, Poirot L, Hattori M, Benoist C, Mathis D: Physiological beta cell death triggers priming of self-reactive T cells by dendritic cells in a type-1 diabetes model. J Exp Med 198:1527-1537, 2003

[69] Todd JA: Genetic control of autoimmunity in type 1 diabetes. Immunol Today 11:122-129, 1990

[70] Wallberg M, Wong FS, Green EA: An islet-specific pulse of TGF-(beta) abrogates CTL function and promotes (beta) cell survival independent of Foxp3+ T cells. J Immunol 186:2543-2551, 2011

[71] Amrani A, Verdaguer J, Thiessen S, Bou S, Santamaria P: IL-1alpha, IL-1beta, and IFNgamma mark beta cells for Fas-dependent destruction by diabetogenic CD4(+) T lymphocytes. J Clin Invest 105:459-468, 2000

[72] Mandrup-Poulsen T: Beta cell death and protection. Ann N Y Acad Sci 1005:32-42, 2003

[73] Suarez-Pinzon W, Sorensen O, Bleackley RC, Elliott JF, Rajotte RV, Rabinovitch A: Betacell destruction in NOD mice correlates with Fas (CD95) expression on beta-cells and proinflammatory cytokine expression in islets. Diabetes 48:21-28, 1999

[74] Yamada K, Takane-Gyotoku N, Yuan X, Ichikawa F, Inada C, Nonaka K: Mouse islet cell lysis mediated by interleukin-1-induced Fas. Diabetologia 39:1306-1312, 1996

[75] Moriwaki M, Itoh N, Miyagawa J, Yamamoto K, Imagawa A, Yamagata K, Iwahashi H, Nakajima H, Namba M, Nagata S, Hanafusa T, Matsuzawa Y: Fas and Fas ligand 
expression in inflamed islets in pancreas sections of patients with recent-onset Type I diabetes mellitus. Diabetologia 42:1332-1340, 1999

[76] Imagawa A, Hanafusa T, Tamura S, Moriwaki M, Itoh N, Yamamoto K, Iwahashi H, Yamagata K, Waguri M, Nanmo T, Uno S, Nakajima H, Namba M, Kawata S, Miyagawa JI, Matsuzawa Y: Pancreatic biopsy as a procedure for detecting in situ autoimmune phenomena in type 1 diabetes: close correlation between serological markers and histological evidence of cellular autoimmunity. Diabetes 50:1269-1273, 2001

[77] Loweth AC, Williams GT, James RF, Scarpello JH, Morgan NG: Human islets of Langerhans express Fas ligand and undergo apoptosis in response to interleukin1beta and Fas ligation. Diabetes 47:727-732, 1998

[78] Apostolou I, Hao Z, Rajewsky K, von Boehmer H: Effective destruction of Fas-deficient insulin-producing beta cells in type 1 diabetes. J Exp Med 198:1103-1106, 2003

[79] Allison J, Thomas HE, Catterall T, Kay TW, Strasser A: Transgenic expression of dominant-negative Fas-associated death domain protein in beta cells protects against Fas ligand-induced apoptosis and reduces spontaneous diabetes in nonobese diabetic mice. J Immunol 175:293-301, 2005

[80] Tiedge M, Lortz S, Drinkgern J, Lenzen S: Relation between antioxidant enzyme gene expression and antioxidative defense status of insulin-producing cells. Diabetes 46:1733-1742, 1997

[81] Thomas HE, McKenzie MD, Angstetra E, Campbell PD, Kay TW: Beta cell apoptosis in diabetes. Apoptosis 14:1389-1404, 2009

[82] Lenzen S, Drinkgern J, Tiedge M: Low antioxidant enzyme gene expression in pancreatic islets compared with various other mouse tissues. Free Radic Biol Med 20:463-466, 1996

[83] Hotta M, Tashiro F, Ikegami H, Niwa H, Ogihara T, Yodoi J, Miyazaki J: Pancreatic beta cell-specific expression of thioredoxin, an antioxidative and antiapoptotic protein, prevents autoimmune and streptozotocin-induced diabetes. J Exp Med 188:14451451,1998

[84] Li X, Chen H, Epstein PN: Metallothionein protects islets from hypoxia and extends islet graft survival by scavenging most kinds of reactive oxygen species. J Biol Chem 279:765-771, 2004

[85] Chen H, Li X, Epstein PN: MnSOD and catalase transgenes demonstrate that protection of islets from oxidative stress does not alter cytokine toxicity. Diabetes 54:1437-1446, 2005

[86] Lortz S, Tiedge M, Nachtwey T, Karlsen AE, Nerup J, Lenzen S: Protection of insulinproducing RINm5F cells against cytokine-mediated toxicity through overexpression of antioxidant enzymes. Diabetes 49:1123-1130, 2000

[87] Naik E, Dixit VM: Mitochondrial reactive oxygen species drive proinflammatory cytokine production. J Exp Med 208:417-420, 2011

[88] Bulua AC, Simon A, Maddipati R, Pelletier M, Park H, Kim KY, Sack MN, Kastner DL, Siegel RM: Mitochondrial reactive oxygen species promote production of proinflammatory cytokines and are elevated in TNFR1-associated periodic syndrome (TRAPS). J Exp Med 208:519-533, 2011

[89] Peritt D: Potential mechanisms of photopheresis in hematopoietic stem cell transplantation. Biol Blood Marrow Transplant 12:7-12, 2006

[90] Hivelin M, Siemionow M, Grimbert P, Lantieri L: Extracorporeal photopheresis: from solid organs to face transplantation. Transpl Immunol 21:117-128, 2009

[91] Scarisbrick J: Extracorporeal photopheresis: what is it and when should it be used? Clin Exp Dermatol 34:757-760, 2009 
[92] Knobler R, Barr ML, Couriel DR, Ferrara JL, French LE, Jaksch P, Reinisch W, Rook AH, Schwarz T, Greinix H: Extracorporeal photopheresis: past, present, and future. J Am Acad Dermatol 61:652-665, 2009

[93] Marshall SR: Technology insight: ECP for the treatment of GvHD--can we offer selective immune control without generalized immunosuppression? Nat Clin Pract Oncol 3:302-314, 2006

[94] Miller JD, Kirkland EB, Domingo DS, Scull H, Jekutis B, Dallas M, Cooper KD, Baron ED: Review of extracorporeal photopheresis in early-stage (IA, IB, and IIA) cutaneous T-cell lymphoma. Photodermatol Photoimmunol Photomed 23:163-171, 2007

[95] Zic JA: The treatment of cutaneous T-cell lymphoma with photopheresis. Dermatol Ther $16: 337-346,2003$

[96] Greinix HT, Socie G, Bacigalupo A, Holler E, Edinger MG, Apperley JF, Schwarz T, Ullrich SE, Albert ML, Knobler RM, Peritt D, Ferrara JL: Assessing the potential role of photopheresis in hematopoietic stem cell transplant. Bone Marrow Transplant 38:265-273, 2006

[97] Greinix HT, Knobler RM, Worel N, Schneider B, Schneeberger A, Hoecker P, Mitterbauer M, Rabitsch W, Schulenburg A, Kalhs P: The effect of intensified extracorporeal photochemotherapy on long-term survival in patients with severe acute graft-versus-host disease. Haematologica 91:405-408, 2006

[98] Couriel DR, Hosing C, Saliba R, Shpall EJ, Anderlini P, Rhodes B, Smith V, Khouri I, Giralt S, de Lima M, Hsu Y, Ghosh S, Neumann J, Andersson B, Qazilbash M, Hymes S, Kim S, Champlin R, Donato M: Extracorporeal photochemotherapy for the treatment of steroid-resistant chronic GVHD. Blood 107:3074-3080, 2006

[99] Marques MB, Schwartz J: Update on extracorporeal photopheresis in heart and lung transplantation. J Clin Apher 2010 Dec 6 (Epub ahead of print)

[100] Suchin KR, Cassin M, Washko R, Nahass G, Berkson M, Stouch B, Vowels BR, Rook AH: Extracorporeal photochemotherapy does not suppress T- or B-cell responses to novel or recall antigens. J Am Acad Dermatol 41:980-986, 1999

[101] Xia CQ, Chernatynskaya A, Lai Y, Campbell KA, Clare-Salzler MJ: Experimental extracorporeal photopheresis therapy significantly delays the development of diabetes in non-obese diabetic mice. Clin Immunol 135:374-383, 2010

[102] Xia CQ, Qiu Y, Peng RH, Lo-Dauer J, Clare-Salzler MJ: Infusion of UVB-treated splenic stromal cells induces suppression of beta cell antigen-specific T cell responses in NOD mice. J Autoimmun 30:283-292, 2008

[103] Xia CQ, Peng R, Qiu Y, Annamalai M, Gordon D, Clare-Salzler MJ: Transfusion of apoptotic beta-cells induces immune tolerance to beta-cell antigens and prevents type 1 diabetes in NOD mice. Diabetes 56:2116-2123, 2007

[104] McKenna KE, Whittaker S, Rhodes LE, Taylor P, Lloyd J, Ibbotson S, Russell-Jones R: Evidence-based practice of photopheresis 1987-2001: a report of a workshop of the British Photodermatology Group and the U.K. Skin Lymphoma Group. $\mathrm{Br} \mathrm{J}$ Dermatol 154:7-20, 2006

[105] Ludvigsson J, Samuelsson U, Ernerudh J, Johansson C, Stenhammar L, Berlin G: Photopheresis at onset of type 1 diabetes: a randomised, double blind, placebo controlled trial. Arch Dis Child 85:149-154, 2001

[106] Malawista SE, Trock D, Edelson RL: Photopheresis for rheumatoid arthritis. Ann N Y Acad Sci 636:217-226, 1991

[107] Zic JA, Miller JL, Stricklin GP, King LE, Jr.: The North American experience with photopheresis. Ther Apher 3:50-62, 1999 
[108] Menkes CJ, Andreu G, Heshmati F, Hilliquin P: Extracorporeal photochemotherapy. $\mathrm{Br}$ J Rheumatol 31:789-790, 1992

[109] Laroux FS, Pavlick KP, Wolf RE, Grisham MB: Dysregulation of intestinal mucosal immunity: implications in inflammatory bowel disease. News Physiol Sci 16:272-277, 2001

[110] Lim WC, Hanauer SB: Controversies with aminosalicylates in inflammatory bowel disease. Rev Gastroenterol Disord 4:104-117, 2004

[111] Reinisch W, Nahavandi H, Santella R, Zhang Y, Gasche C, Moser G, Waldhor T, Gangl A, Vogelsang H, Knobler R: Extracorporeal photochemotherapy in patients with steroid-dependent Crohn's disease: a prospective pilot study. Aliment Pharmacol Ther 15:1313-1322, 2001

[112] Abreu MT, von Tirpitz C, Hardi R, Kaatz M, Van Assche G, Rutgeerts P, Bisaccia E, Goerdt S, Hanauer S, Knobler R, Mannon P, Mayer L, Ochsenkuhn T, Sandborn WJ, Parenti D, Lee K, Reinisch W: Extracorporeal photopheresis for the treatment of refractory Crohn's disease: results of an open-label pilot study. Inflamm Bowel Dis 15:829-836, 2009

[113] Parnaik R, Raff MC, Scholes J: Differences between the clearance of apoptotic cells by professional and non-professional phagocytes. Curr Biol 10:857-860, 2000

[114] Tanaka M, Asano K, Qiu CH: Immune regulation by apoptotic cell clearance. Ann N Y Acad Sci 1209:37-42, 2010

[115] Steinman RM, Hawiger D, Liu K, Bonifaz L, Bonnyay D, Mahnke K, Iyoda T, Ravetch J, Dhodapkar M, Inaba K, Nussenzweig M: Dendritic cell function in vivo during the steady state: a role in peripheral tolerance. Ann N Y Acad Sci 987:15-25, 2003

[116] Liu K, Iyoda T, Saternus M, Kimura Y, Inaba K, Steinman RM: Immune tolerance after delivery of dying cells to dendritic cells in situ. J Exp Med 196:1091-1097, 2002

[117] Mueller DL: Mechanisms maintaining peripheral tolerance. Nat Immunol 11:21-27, 2010

[118] Savill J, Dransfield I, Gregory C, Haslett C: A blast from the past: clearance of apoptotic cells regulates immune responses. Nat Rev Immunol 2:965-975, 2002

[119] Voll RE, Herrmann M, Roth EA, Stach C, Kalden JR, Girkontaite I: Immunosuppressive effects of apoptotic cells. Nature 390:350-351, 1997

[120] Fadok VA, Bratton DL, Konowal A, Freed PW, Westcott JY, Henson PM: Macrophages that have ingested apoptotic cells in vitro inhibit proinflammatory cytokine production through autocrine/paracrine mechanisms involving TGF-beta, PGE2, and PAF. J Clin Invest 101:890-898, 1998

[121] Fadok VA, McDonald PP, Bratton DL, Henson PM: Regulation of macrophage cytokine production by phagocytosis of apoptotic and post-apoptotic cells. Biochem Soc Trans 26:653-656, 1998

[122] Chen W, Frank ME, Jin W, Wahl SM: TGF-beta released by apoptotic T cells contributes to an immunosuppressive milieu. Immunity 14:715-725, 2001

[123] Stark MA, Huo Y, Burcin TL, Morris MA, Olson TS, Ley K: Phagocytosis of apoptotic neutrophils regulates granulopoiesis via IL-23 and IL-17. Immunity 22:285-294, 2005

[124] Bettelli E, Carrier Y, Gao W, Korn T, Strom TB, Oukka M, Weiner HL, Kuchroo VK: Reciprocal developmental pathways for the generation of pathogenic effector TH17 and regulatory T cells. Nature 441:235-238, 2006

[125] Lamioni A, Parisi F, Isacchi G, Giorda E, Di Cesare S, Landolfo A, Cenci F, Bottazzo GF, Carsetti R: The immunological effects of extracorporeal photopheresis unraveled: induction of tolerogenic dendritic cells in vitro and regulatory $\mathrm{T}$ cells in vivo. Transplantation 79:846-850, 2005 
[126] Roncarolo MG, Bacchetta R, Bordignon C, Narula S, Levings MK: Type 1 T regulatory cells. Immunol Rev 182:68-79, 2001

[127] Groux H, O'Garra A, Bigler M, Rouleau M, Antonenko S, de Vries JE, Roncarolo MG: A CD4+ T-cell subset inhibits antigen-specific T-cell responses and prevents colitis. Nature 389:737-742, 1997

[128] Sakaguchi S, Sakaguchi N, Shimizu J, Yamazaki S, Sakihama T, Itoh M, Kuniyasu Y, Nomura T, Toda M, Takahashi T: Immunologic tolerance maintained by CD25+ CD4+ regulatory $\mathrm{T}$ cells: their common role in controlling autoimmunity, tumor immunity, and transplantation tolerance. Immunol Rev 182:18-32, 2001

[129] Hori S, Nomura T, Sakaguchi S: Control of regulatory T cell development by the transcription factor Foxp3. Science 299:1057-1061, 2003

[130] Wang Z, Larregina AT, Shufesky WJ, Perone MJ, Montecalvo A, Zahorchak AF, Thomson AW, Morelli AE: Use of the inhibitory effect of apoptotic cells on dendritic cells for graft survival via T-cell deletion and regulatory T cells. Am J Transplant 6:1297-1311, 2006

[131] George JF, Gooden CW, Guo L, Kirklin JK: Role for CD4(+)CD25(+) T cells in inhibition of graft rejection by extracorporeal photopheresis. J Heart Lung Transplant 27:616-622, 2008

[132] Maeda A, Schwarz A, Kernebeck K, Gross N, Aragane Y, Peritt D, Schwarz T: Intravenous infusion of syngeneic apoptotic cells by photopheresis induces antigen-specific regulatory T cells. J Immunol 174:5968-5976, 2005

[133] Maeda A, Schwarz A, Bullinger A, Morita A, Peritt D, Schwarz T: Experimental extracorporeal photopheresis inhibits the sensitization and effector phases of contact hypersensitivity via two mechanisms: generation of IL-10 and induction of regulatory T cells. J Immunol 181:5956-5962, 2008

[134] Gatza E, Rogers CE, Clouthier SG, Lowler KP, Tawara I, Liu C, Reddy P, Ferrara JL: Extracorporeal photopheresis reverses experimental graft-versus-host disease through regulatory T cells. Blood 112:1515-1521, 2008

[135] Rao V, Saunes M, Jorstad S, Moen T: Cutaneous T cell lymphoma and graft-versushost disease: a comparison of in vivo effects of extracorporeal photochemotherapy on Foxp3+ regulatory T cells. Clin Immunol 133:303-313, 2009

[136] Biagi E, Di Biaso I, Leoni V, Gaipa G, Rossi V, Bugarin C, Renoldi G, Parma M, Balduzzi A, Perseghin P, Biondi A: Extracorporeal photochemotherapy is accompanied by increasing levels of circulating CD4+CD25+GITR+Foxp3+CD62L+ functional regulatory $\mathrm{T}$-cells in patients with graft-versus-host disease. Transplantation 84:31-39, 2007

[137] Jonson CO, Pihl M, Nyholm C, Cilio CM, Ludvigsson J, Faresjo M: Regulatory T cellassociated activity in photopheresis-induced immune tolerance in recent onset type 1 diabetes children. Clin Exp Immunol 153:174-181, 2008 


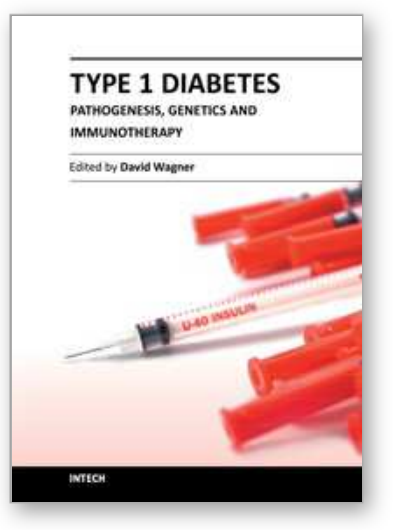

\author{
Type 1 Diabetes - Pathogenesis, Genetics and Immunotherapy \\ Edited by Prof. David Wagner
}

ISBN 978-953-307-362-0

Hard cover, 660 pages

Publisher InTech

Published online 25, November, 2011

Published in print edition November, 2011

This book is a compilation of reviews about the pathogenesis of Type 1 Diabetes. T1D is a classic autoimmune disease. Genetic factors are clearly determinant but cannot explain the rapid, even overwhelming expanse of this disease. Understanding etiology and pathogenesis of this disease is essential. A number of experts in the field have covered a range of topics for consideration that are applicable to researcher and clinician alike. This book provides apt descriptions of cutting edge technologies and applications in the ever going search for treatments and cure for diabetes. Areas including T cell development, innate immune responses, imaging of pancreata, potential viral initiators, etc. are considered.

\title{
How to reference
}

In order to correctly reference this scholarly work, feel free to copy and paste the following:

Chang-Qing Xia, Kim Campbell, Benjamin Keselowsky and Michael Clare-Salzler (2011). Steady-State Cell Apoptosis and Immune Tolerance - Induction of Tolerance Using Apoptotic Cells in Type 1 Diabetes and Other Immune-Mediated Disorders, Type 1 Diabetes - Pathogenesis, Genetics and Immunotherapy, Prof. David Wagner (Ed.), ISBN: 978-953-307-362-0, InTech, Available from: http://www.intechopen.com/books/type-1diabetes-pathogenesis-genetics-and-immunotherapy/steady-state-cell-apoptosis-and-immune-toleranceinduction-of-tolerance-using-apoptotic-cells-in-typ

\section{INTECH}

open science | open minds

\author{
InTech Europe \\ University Campus STeP Ri \\ Slavka Krautzeka 83/A \\ 51000 Rijeka, Croatia \\ Phone: +385 (51) 770447 \\ Fax: +385 (51) 686166 \\ www.intechopen.com
}

\author{
InTech China \\ Unit 405, Office Block, Hotel Equatorial Shanghai \\ No.65, Yan An Road (West), Shanghai, 200040, China \\ 中国上海市延安西路65号上海国际贵都大饭店办公楼 405 单元 \\ Phone: +86-21-62489820 \\ Fax: $+86-21-62489821$
}


(C) 2011 The Author(s). Licensee IntechOpen. This is an open access article distributed under the terms of the Creative Commons Attribution 3.0 License, which permits unrestricted use, distribution, and reproduction in any medium, provided the original work is properly cited. 